\title{
Clinical, radiographic and histologic findings, therapy and outcome in 15 horses with suture periostitis: a case series
}

\author{
Linda Klein', Anton E. Fürst' ${ }^{1}$, Francesca Del Chicca², Felix Theiss' and Michelle A. Jackson' \\ ${ }^{1}$ Equine Department and ${ }^{2}$ Clinic of Diagnostic Imaging Vetsuisse-Faculty, University of Zurich, Zurich, Switzerland
}

\begin{abstract}
Summary: There are few reports describing suture periostitis (SP) in horses. This case series outlines the clinical, radiographic and histologic features of SP and compares various types of treatment in 15 horses presented to the Equine Clinic, Vetsuisse-Faculty, University of Zurich. Overall, the incidence of horses with SP presented to our clinic was low, and clinical signs were similar to those previously reported. Radiography was used to diagnose SP, but computed tomography was the imaging modality of choice for determining the extent of the bony changes and the suture lines affected. Horses that underwent surgical stabilization had more rapid resolution of signs than those treated conservatively or not treated at all.
\end{abstract}

Keywords: suture periostitis, suturitis, suture lines, facial swelling, epiphora, head

Citation: Klein L., Fürst A. E., Del Chicca F., Theiss F., Jackson M. A. (2019) Clinical, radiographic and histologic findings, therapy and outcome in 15 horses with suture periostitis: a case series. Pferdeheilkunde 35, 204-210; DOI 10.21836/PEM20190301

Correspondence: Dr. med. vet. PhD Michelle A. Jackson, Equine Hospital, Vetsuisse-Faculty, University of Zurich, Winterthurerstrasse 260, 8057 Zurich, Switzerland; mjackson@vetclinics.uzh.ch

Received: March 15, 2019 | Accepted: April 10, 2019

\section{Introduction}

Suture periostitis (SP), also called suture exostosis or suturitis, is a rare condition in horses characterized by a transverse, firm, unilateral or bilateral swelling in the frontal region of the head (Dixon 1991, Carslake 2009). The nasofrontal suture line at the level of the rostral aspect of the orbits is most often affected (Gibbs and Lane 1987, Tremaine and Dixon 2002), whereas the nasolacrimal (Dixon 1991, Tremaine and Dixon 2001) and maxillolacrimal sutures (Carslake 2009) are less commonly involved. Possible causes of SP include trauma (Dixon 1991), previous surgical sinusotomy (Dixon 1991, Tremaine and Freeman 2006, Fenner et al. 2018) and instability attributable to chronic fracture (Klein et al. 2014). However, the exact etiology of this condition is unknown.

Although SP has been infrequently described in the veterinary literature, there are similarities among reported cases. For example, most of the horses did not have distinct clinical signs apart from a firm, non-painful swelling rostral to the eyes (Lane et al. 1987). Some horses had persistent uni- or bilateral epiphora (Mcllnay et al. 2001, Ramzan and Payne 2005). The most common radiographic finding was proliferative periosteal changes in the nasofrontal suture line, which was wider than normal and not completely closed (Tremaine and Freeman 2006). However, the extent and pattern of the proliferative lesions were highly variable (Tremaine and Dixon 2002, Manso-Díaz and Taeymans 2012).

Treatment for SP varies among reports (Dixon 2014), and in cases that received no therapy, the swelling disappeared within 12 months of diagnosis (Dixon 2014). In other cases, surgical intervention was chosen to decrease the time required for resolution of signs (Manso-Diaz and Taeymans 2012). In one adult horse, stabilization of the nasofrontal suture lines with two $2.4 \mathrm{~mm}$ Unilock plates led to resolution of the swelling and other signs including epiphora within six months (Klein et al. 2014).

Information about SP, available treatment options and associated outcomes in horses is sparse. Therefore, the aim of the present study was to describe a case series of horses with SP and to compare the outcome after conservative management, surgical intervention or no treatment.

\section{Case histories and clinical findings}

The case records of 15 horses with SP presented to the Equine Hospital, University of Zurich, between 1995 and 2016, were reviewed retrospectively. In all cases, a diagnosis of SP was made based on the clinical signs (bony facial swellings with or without epiphora) and radiographic findings (periosteal and endosteal bone proliferation in the area of the nasofrontal suture line). Information regarding patient data, case background, clinical signs and their duration before presentation, radiographic results, treatment and outcome were collected. The age of the horses ranged from six to 17 years, with a mean ( \pm s.d.) of $9.4 \pm 3.3$ years. There were 10 geldings and five mares, and breeds included: Warmblood (10), Thoroughbred (3) and Quarter horse (2). The duration of clinical signs before presentation ranged from two weeks to 24 months. A summary of the patient data and the clinical details are shown in Table 1.

All patients were presented for evaluation of bony swellings of the nasofrontal region. The swellings were firm in all cases, and none of the horses reacted to deep palpation of the 
region. Thirteen horses had symmetric bilateral and two had asymmetric unilateral bony exostosis in the region of the nasofrontal suture (Fig 1).

Seven cases had unilateral (4/7) or bilateral (3/7) epiphora. Headshaking was reported in two horses, and one horse had subcutaneous emphysema surrounding the swelling. In all horses, physical examination showed no obvious reason for the swelling, and there was no history of previous surgical intervention or trauma.

\section{Diagnostics}

Lateral, oblique $\left(30^{\circ}\right)$ and dorsoventral radiographic views of the nasofrontal region of the affected bones were taken in all cases. All radiographs were reviewed by a board-certified radiologist (FDC). New periosteal bone formation was seen in all projections and was most obvious in the lateral views

Table 1 Patient signalment and results of physical examination in 15 horses with suture periostitis. Swelling occurred on the head between the eyes and involved mainly the nasofrontal suture. Signalement und klinische Befunde von 15 Pferden mit Suture Periostitis. Die Lokalisation der knöchernen Schwellung befindet sich am Kopf im Bereich der nasofrontalen Schädelnaht.

\begin{tabular}{|c|c|c|c|c|c|}
\hline Case & $\begin{array}{l}\text { Age } \\
\text { (years) }\end{array}$ & Breed & Sex & Clinical signs & $\begin{array}{l}\text { Duration } \\
\text { of clinical } \\
\text { signs* }\end{array}$ \\
\hline 1 & 7 & TB & M & $\begin{array}{l}\text { Symmetric swelling } \\
\text { Headshaking }\end{array}$ & 6 months \\
\hline 2 & 10 & WB & G & $\begin{array}{c}\text { Unilateral swelling (left) } \\
\text { Epiphora (left) }\end{array}$ & $\begin{array}{l}3 \text { weeks } \\
5 \text { years }\end{array}$ \\
\hline 3 & 11 & WB & $M$ & Unilateral swelling (right) & 2 months \\
\hline 4 & 11 & WB & $G$ & Symmetric swelling & 3 months \\
\hline 5 & 10 & WB & $G$ & Symmetric swelling & 2 months \\
\hline 6 & 13 & WB & $G$ & $\begin{array}{l}\text { Symmetric swelling } \\
\text { Bilateral epiphora }\end{array}$ & 2 months \\
\hline 7 & 7 & WB & G & $\begin{array}{l}\text { Symmetric swelling } \\
\text { Bilateral epiphora }\end{array}$ & 1 month \\
\hline 8 & 6 & QH & G & $\begin{array}{c}\text { Symmetric swelling } \\
\text { Epiphora (left) }\end{array}$ & 3 weeks \\
\hline 9 & 10 & TB & M & $\begin{array}{l}\text { Symmetric swelling } \\
\text { Bilateral epiphora }\end{array}$ & 3 weeks \\
\hline 10 & 13 & QH & G & $\begin{array}{c}\text { Symmetric swelling } \\
\text { Epiphora (right) } \\
\text { Headshaking }\end{array}$ & 1 month \\
\hline 11 & 6 & WB & G & Symmetric swelling & 2 months \\
\hline 12 & 17 & WB & G & Symmetric swelling & 5 months \\
\hline 13 & 8 & WB & $M$ & $\begin{array}{l}\text { Symmetric swelling } \\
\text { Bilateral epiphora }\end{array}$ & 5 months \\
\hline 14 & 6 & TB & $M$ & Symmetric swelling & 6 months \\
\hline 15 & 6 & WB & G & $\begin{array}{c}\text { Symmetric swelling } \\
\text { Emphysema }\end{array}$ & 2 weeks \\
\hline
\end{tabular}

*The time frame between occurrence of the problem to presentation of the horse. TB, Thoroughbred; WB, Warmblood; QH, Quarter horse; M, mare; G, gelding * Zeit zwischen dem Auftreten der Symptome und der Vorstellung der Patienten. TB, Vollbut; WB, Warmblut; QH, Quarter Horse; M, Stute; G, Wallach
(Fig 2). In all cases, the nasofrontal suture line was affected with radiographic evidence of periosteal new bone formation. Of the 15 cases, widening of the suture line was seen in 13, well-marginated bone proliferation in seven and irregularly-marginated bone proliferation in eight. Four of 15 cases had soft tissue swelling, which was mild in three and moderate in one. Localization of the bony changes varied. A line was drawn on the lateral radiographic view perpendicular to the frontal bone. This line was centered either over the area of bone discontinuity, when visible, or, in the absence of bone discontinuity, over the area of maximum thickness of new bone formation. The location at which this line crossed the roots of the teeth was recorded (Fig 3). This line crossed the caudal tooth root of the second molar (110 and 210) in three cases, the rostral tooth root of the third molar (111 and 211) in seven cases and the caudal tooth root of 111/211 in five. Additional diagnostic techniques were carried out as required. Two horses underwent endoscopic examination of the nasal cavity, which showed no abnormalities in one case and a small amount of mucus near the ethmoid in the other.

Computed tomography (CT) using a 40 slice helical CT scanner (Somatom Sensation Open, Siemens AG, Switzerland) was carried out in five horses in dorsal recumbency and un-

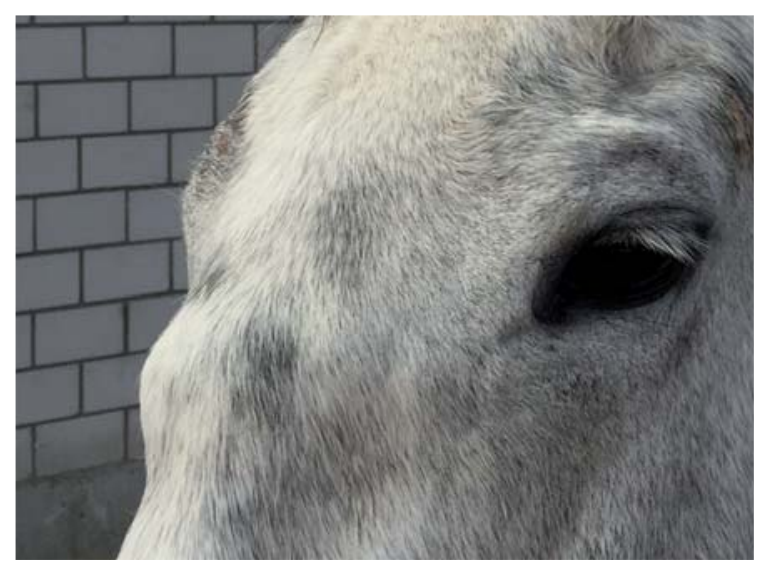

Fig. 1 Horse presented with firm, bilateral and non-painful swelling in the nasofrontal region | Ein Patient vorgestellt mit einer derben, bilateralen, nicht-dolenten Schwellung im Bereich der nasofrontalen Sutur

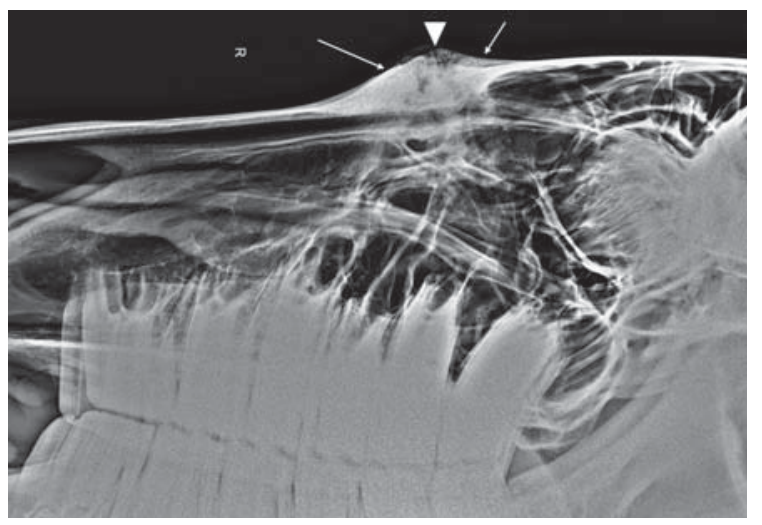

Fig. 2 Lateral radiographic view of the same horse shown in Fig. 1 showing new periosteal bone formation (arrows) and widening of the nasofrontal suture line (arrow head) | Das laterale Röntgenbild des Pferdes von Fig. 1 zeigt knöcherne periostale Zubildungen (Pfeile) sowie eine Verbreiterung der nasofrontalen Sutur (Pfeilkopf) 
der general anesthesia. An indwelling catheter was placed in a jugular vein, and the horses were premedicated with penicillin $\mathrm{G}(30,000 \mathrm{IU} / \mathrm{kg}$ intravenously [IV])', gentamicin $(7 \mathrm{mg} / \mathrm{kg}[\mathrm{IV}])^{2}$ and flunixin meglumine $(1.1 \mathrm{mg} / \mathrm{kg}[\mathrm{IV}])^{3}$. The horses were sedated with acepromazine $(0.03 \mathrm{mg} / \mathrm{kg}$ intramuscularly $[\mathrm{IM}])^{4}$ and medetomidine $(0.01 \mathrm{mg} / \mathrm{kg}[\mathrm{IV}])^{3}$, and anesthesia was induced with ketamine $(2 \mathrm{mg} / \mathrm{kg}[\mathrm{IV}])^{5}$ and diazepam $(0.2 \mathrm{mg} / \mathrm{kg}[\mathrm{IV}])^{6}$. An endotracheal tube was placed, and anesthesia was maintained with isoflurane. CT images were obtained using settings of $120 \mathrm{kV}$ and $100 \mathrm{mAs}$, $1 \mathrm{~s}$ tube rotation time, a pitch of 0.65 , and $2 \mathrm{~mm}$ slice collimation with an increment of $2 \mathrm{~mm}$ reconstructed to $0.75 \mathrm{~mm}$ using a medium-frequency image reconstruction algorithm (soft tissue) and a high-frequency image reconstruction algorithm (bone). CT enabled characterization of the exact localization and extent of the SP as well as assessment of the lacrimal duct, sinuses and soft tissues. In the five horses that underwent CT examination, the frontolacrimal suture was involved in addition to the nasofrontal suture line. The bone proliferation involved externally the wall of the lacrimal duct in two of these five horses (Fig 4). In the horse with subcutaneous emphysema (Case 15), CT revealed retrobulbar gas accumulation. Table 2 provides a summary of the CT findings in five horses with SP.

\section{Treatment and outcome}

Treatment and outcome of the 15 horses with SP are summarized in Table 3. Nine cases received no treatment. Three horses were treated conservatively; two received daily oral administration of phenylbutazone $(2.2 \mathrm{mg} / \mathrm{kg}$ [Equipalazone $1000 \mathrm{mg} / 1.59 \mathrm{~g}$ powder for oral application $]^{8}$ ) for seven and 14 days, respectively, and the other was treated with topical application of Dimethylsulfoxid (DMSO). Three cases with severe bony changes underwent surgical treatment under general anesthesia immediately after CT examination because bone instability was suspected. The horses were anesthetized and placed on the operating table in lateral recumbency. The surgical area was clipped and prepared for aseptic surgery. Two $10 \mathrm{~cm}$ paramedian, rostrocaudal incisions were made approximately three $\mathrm{cm}$ from the median, centered at the level of the frontonasal suture. The periosteum was elevated, and the callus involving the suture between the frontal and nasal bones was removed revealing a distinct $2 \mathrm{~mm}$ gap between the bones. In two cases, two, 11 hole, $2.4 \mathrm{~mm}$ Unilock plates $^{7}$ were positioned over the affected nasofrontal suture with one plate right and one left of the internasal suture, and fixed with $3 \mathrm{~mm}$ locking screws (4 proximal, 4 distal to the suture) (Fig 5). In the third case, four, 10 hole, $2.4 \mathrm{~mm}$ Unilock
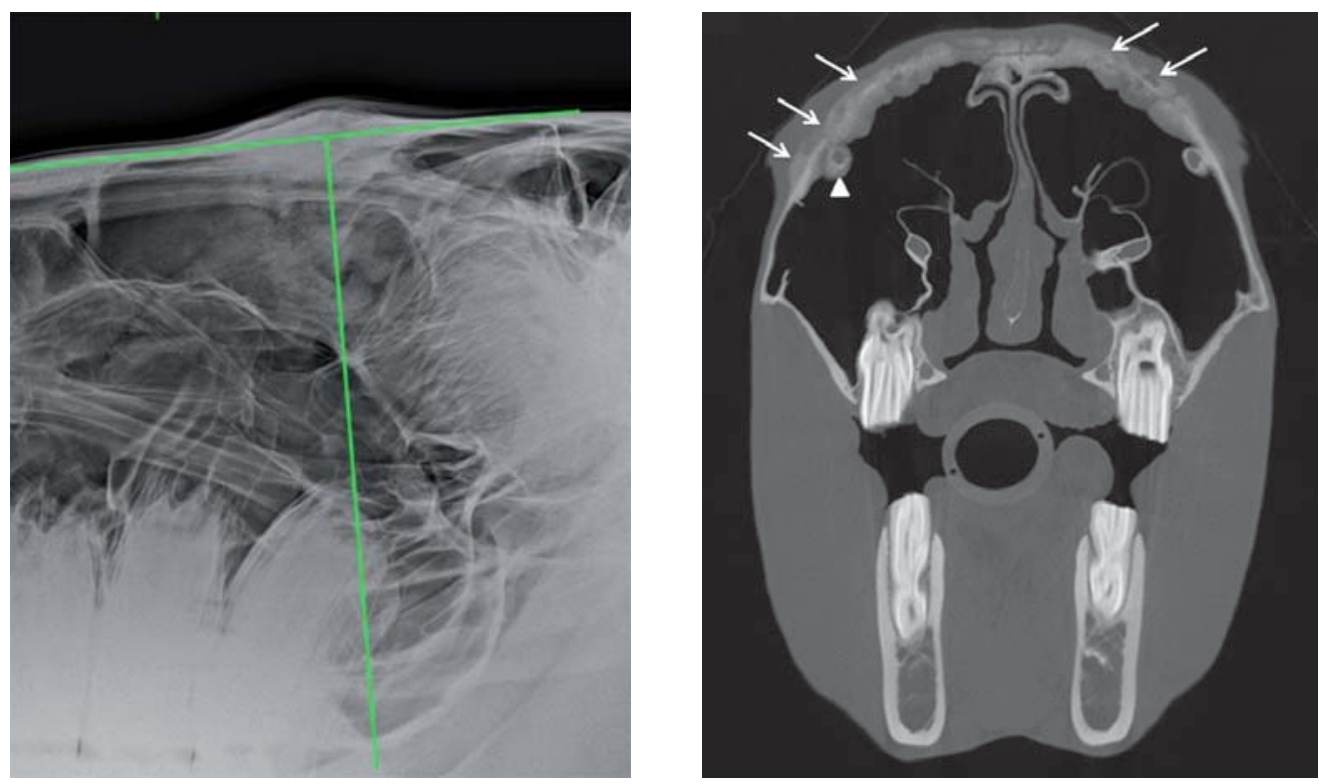

Fig. 3-Fig. 5 from left to right

Fig. 3 A line was drawn on the lateral radiographic view perpendicular to the frontal bone centred over the area of the bony changes to the roots of the teeth. In this horse, the bony changes are at the level of the caudal root of 111/211 | Messungen mittels einer senkrechten Verlängerung von der röntgendurchlässigen Linie zu den Zahnwurzeln des Oberkiefers wurden gemacht. Die rostrokaudale Lokalisation der Suturen, bei diesem Pferd auf Höhe der kaudalen Zahnwurzel von $111 / 211$, konnte gezeigt werden

Fig. 4 Transverse CT image (frontal view) at the level of the second molars. New bone proliferation (arrows) in the region of the nasofrontal and the frontolacrimal suture lines with bony thickening involving the right lacrimal duct (arrows) are visible | In der transversalen computertomographischen Aufnahme auf Höhe des zweiten Molaren ist die periostale Proliferation (Pfeile) in der Region der nasofrontalen sowie der frontolacrimalen Sutur sichtbar. Zudem kann die knöcherne Verdickung sowie die Verengung des Ductus nasolacrimales (Pfeilkopf) gesehen werden

Fig. 5 Two cases were treated surgically, with two 11 hole, $2.4 \mathrm{~mm}$ Unilock plates ${ }^{7}$ over the affected nasofrontal suture. One plate was positioned right and one left of the internasal suture and fixed with $3 \mathrm{~mm}$ locking screws (4 proximal, 4 distal to the suture). In one horse four 10 hole, 2.4 -mm Unilock plates ${ }^{7}$ were used for stabilization with two plates placed on each side of the internasal suture. I Drei Pferde erhielten eine chirurgische Stabilisation der betroffenen Suturen unter Allgemeinanästhesie. Dabei wurden bei zwei Patienten die nasofrontale Sutur mittels je einer 11 Loch, 2,4 mm Unilock Platte ${ }^{7}$ links und rechts der internasalen Sutur fixiert, einem Pferd wurden vier 10 Loch, 2,4 mm Unilock Platten ${ }^{7}$ implantiert, jeweils zwei links und zwei rechts der internasalen Sutur 
plates $^{7}$ were used with two plates placed on each side of the internasal suture. The wound was closed in two layers. Recovery from anesthesia was uneventful in all cases. Penicillin G $(30,000 \mathrm{IU} / \mathrm{kg}$ QID intravenously [IV])', gentamicin (7 mg/

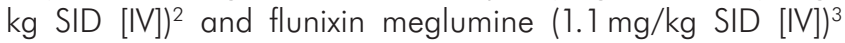
were administered for three days after which phenylbutazone $\left(2.2 \mathrm{mg} / \mathrm{kg}\right.$ [Butasan $320 \mathrm{mg} / \mathrm{ml}$ solution for oral application] ${ }^{6}$ was administered orally, once daily, for one week.

The implants were removed three to 26 months postoperatively. Resolution of the swelling took less than six months in all the three cases that underwent surgical stabilization, less than 12 months in three of the nine cases that received no

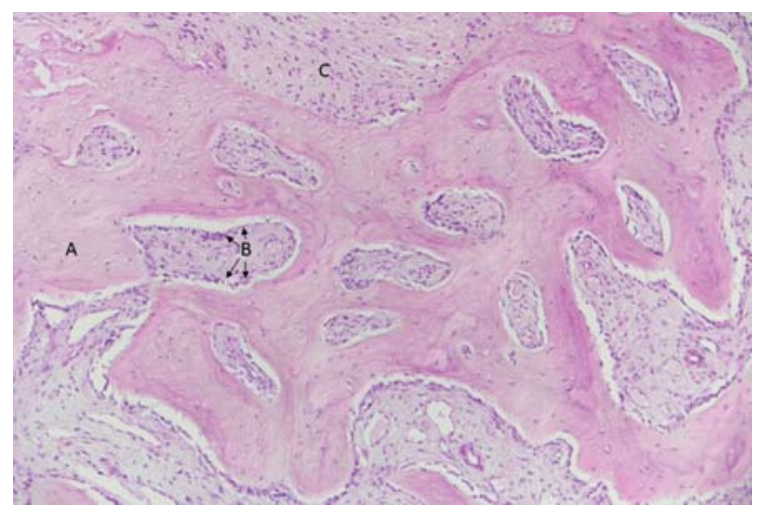

Fig. 6 Histologic section of the proliferative bony lesion in a horse with suture periostitis. Trabeculae of woven bone with (A) peritrabecular bone marrow stromal cells (B) often appearing as fibro-blastoid tissue between the woven bone (C) can be seen. Hematoxilin and eosin stain, 20x | In den histologischen Schnitten der knöchernen Proliferationen bei Pferden mit Suture Periostitis können trabekuläre Strukturen von Geflechtsknochen (A) mit peritrabekulären Knochenmarkszellen (B) und fibroblastisches Bindegewebe (C) im Geflechtsknochen eingebettet gesehen werden. Hämatoxilin und Eosin Färbung, 20x treatment and more than 12 months in the remaining six. Complete resolution of the swelling in the two cases treated conservatively with phenylbutazone took six and 18 months, respectively. One case with topical application of DMSO was lost to follow-up.

\section{Histopathologic findings}

Samples of the proliferative bone lesions were collected in all three horses that underwent surgical treatment, and a biopsy sample of the bony changes was obtained in one horse that did not receive surgical treatment. Samples were fixed in $4 \%$ buffered formalin for 24 hours followed by demineralization in $5 \%$ nitric acid for 24 hours. Afterwards, the samples were embedded in paraffin, and $4 \mu \mathrm{m}$ sections were cut and stained with hematoxylin and eosin stain for histologic examination; the results are summarized in Table 3. All histologic changes were interpreted as callus formation. Infiltration of inflammatory cells was seen in two cases, in which clinical signs had been seen for two weeks and two months, respectively (Fig 6). Infiltration of inflammatory cells was not seen in the other two horses, in which clinical signs had been present for three weeks and two months, respectively.

\section{Discussion}

The goal of the present case series was to characterize the clinical, radiographic and histologic features of 15 horses diagnosed with SP. In addition, the outcome of surgical and conservative treatment as well as no treatment was determined.

It has been reported that young Thoroughbred and Thoroughbred-cross horses are more commonly affected by SP

Table 2 Findings of computed tomography in five horses with suture periostitis | Befunde der computertomographischen Untersuchung von fünf Pferden mit Suture Periostitis

\begin{tabular}{|c|c|c|c|c|c|c|c|}
\hline Case & $\begin{array}{c}\text { Affected } \\
\text { suture lines }\end{array}$ & Symmetry & Lacrimal duct & Sinus & $\begin{array}{l}\text { Soft tissue } \\
\text { changes }\end{array}$ & Bone changes & $\begin{array}{l}\text { Additional unusual } \\
\text { findings }\end{array}$ \\
\hline 4 & $\begin{array}{l}\text { Nasofrontal } \\
\text { and fronto- } \\
\text { lacrimal suture }\end{array}$ & Bilateral & No changes & Normal & $\begin{array}{c}\text { Mild soft tissue } \\
\text { swelling over } \\
\text { bone proliferation }\end{array}$ & $\begin{array}{c}\text { Discontinuity at } \\
\text { the level of the } \\
\text { sutures }\end{array}$ & None \\
\hline 6 & $\begin{array}{l}\text { Nasofrontal } \\
\text { and fronto- } \\
\text { lacrimal suture }\end{array}$ & Bilateral & $\begin{array}{l}\text { Bone thickening } \\
\text { and mild } \\
\text { narrowing of } \\
\text { the right duct }\end{array}$ & $\begin{array}{l}\text { Mild maxillary } \\
\text { sinusitis }\end{array}$ & None & $\begin{array}{l}\text { Multifocal areas } \\
\text { of thinning }\end{array}$ & $\begin{array}{l}\text { Labial fracture of the } \\
\text { crown of } 210, \text { two small } \\
\text { round (up to } 6 \mathrm{~mm} \text { in } \\
\text { diameter) structures } \\
\text { dorsal to } 210 \text { (possible } \\
\text { cementomas) }\end{array}$ \\
\hline 11 & $\begin{array}{l}\text { Nasofrontal } \\
\text { and fronto- } \\
\text { lacrimal suture }\end{array}$ & $\begin{array}{c}\text { Bilateral but more } \\
\text { pronounced on } \\
\text { the right }\end{array}$ & $\begin{array}{l}\text { Focal } \\
\text { thickening and } \\
\text { mild narrowing } \\
\text { the left duct }\end{array}$ & $\begin{array}{l}\text { Fluid line in } \\
\text { the right frontal } \\
\text { sinus }\end{array}$ & $\begin{array}{l}\text { Mild soft tissue } \\
\text { swelling }\end{array}$ & $\begin{array}{l}\text { Discontinuity } \\
\text { at the level of } \\
\text { the sutures and } \\
\text { multifocal lytic } \\
\text { areas }\end{array}$ & $\begin{array}{c}\text { Multiple fragments in the } \\
\text { suture }\end{array}$ \\
\hline 13 & $\begin{array}{l}\text { Nasofrontal, } \\
\text { frontolacrimal } \\
\text { and naso- } \\
\text { lacrimal suture }\end{array}$ & $\begin{array}{c}\text { Bilateral but more } \\
\text { pronounced on } \\
\text { the right }\end{array}$ & No changes & $\begin{array}{l}\text { Small amount } \\
\text { of fluid in the } \\
\text { right frontal } \\
\text { sinus }\end{array}$ & None & $\begin{array}{l}\text { Discontinuity at } \\
\text { the level of the } \\
\text { sutures }\end{array}$ & None \\
\hline 15 & $\begin{array}{l}\text { Nasofrontal } \\
\text { and fronto- } \\
\text { lacrimal suture }\end{array}$ & Bilateral & No changes & Normal & $\begin{array}{l}\text { Moderate soft tis- } \\
\text { sue swelling and } \\
\text { subcutaneous } \\
\text { emphysema }\end{array}$ & $\begin{array}{c}\text { Discontinuity at } \\
\text { the level of the } \\
\text { sutures }\end{array}$ & $\begin{array}{l}\text { Retrobulbar gas } \\
\text { accumulation }\end{array}$ \\
\hline
\end{tabular}


(Gibbs and Lane 1987, Dixon 1991), but the present study could not confirm this. However, approximately $40 \%$ of the equine population in Switzerland is Warmblood horses, and Thoroughbred horses are less common (Agroscope 2016). Accordingly, the majority of horses in the present study were Warmblood horses with a mean age of 9.4 years. Both sexes were affected, but the prevalence of SP was numerically higher in male $(n=10)$ than in female horses $(n=5)$. The number of horses was too small to determine whether this is a deviation from the sex distribution of the Swiss horse population, in which about $50 \%$ are mares (Agroscope 2016). Previous reports on SP in horses did not find a sex predilection (Gibbs and Lane 1987, Dixon 1991).

The clinical signs of SP in the current study were similar to those previously reported, with most of the horses presented because of bilateral swelling in the frontal region of the head. Three horses had unilateral and four had bilateral epiphora. Furthermore, one horse had subcutaneous emphysema surrounding the swelling with unilateral retrobulbar gas accumulation, which has not been reported to date. It is likely that the air originated from the sinus and passed through the open suture line to accumulate subcutaneously.

Radiographic examination confirmed the diagnosis of SP in all cases, but did not allow precise assessment of all the affected suture lines or evaluation of changes of the lacrimal duct because of severe superimposition of bony structures. In all five cases that underwent CT examination, this imaging modality showed that in addition to the nasofrontal suture line, the frontolacrimal suture line was involved. In one case, the adjacent nasolacrimal suture line was also affected, which has been previously described (Dixon 1991, Tremaine and Dixon 2001). In addition, CT revealed bone proliferation on the wall of the nasolacrimal duct in three of the five cases. It has been reported that the maxillolacrimal suture line can also be affected (Carslake 2009), but this suture line was not involved in any of our cases.

Our observations have shown that the location of the bony changes can vary anatomically at a rostrocaudal level. In one study, a line drawn perpendicular to the frontal bone at the level of the frontonasal suture on a lateral radiograph was used to divide the skull into cranial and nasal portions (Evans and McGreevey 2006). It was determined that the frontonasal suture line was always located at the level of the orbit, crossing the check teeth caudal to 111/211 (Evans and McGreevey 2006). In contrast, the results of our study showed that this same line crossed the caudal tooth root of $111 / 211$ in only five cases, whereas it crossed the rostral tooth root of $111 / 211$ in seven cases and the caudal tooth root of $110 / 210$ in three cases. Therefore, we hypothesize that frontonasal sutures of horses not only have unique deviations (Evans and McGreevey 2006) but also individual anatomic localization at a rostrocaudal level.

Table 3 Summary of treatment, time to resolution and histologic findings in 15 horses with suture periostitis | Zusammenfassung der therapeutischen Intervention, der Zeit bis zur vollständigen Abheilung und der histologischen Befunde in 15 Pferde mit Suture Periostitis

\begin{tabular}{|c|c|c|c|c|}
\hline Case & Treatment & Time to resolution & Histologic Findings & Follow-up \\
\hline 1 & $\begin{array}{c}\text { Topical application of } \\
\text { DMSO }\end{array}$ & LTF & & LTF \\
\hline 2 & NT & within 24 months & $\begin{array}{l}\text { Callus formation with no infiltration } \\
\text { of inflammatory cells }\end{array}$ & \\
\hline 3 & NT & within 24 months & & \\
\hline 4 & NT & within 5 months & & \\
\hline 5 & NT & within 24 months & & \\
\hline 6 & $\begin{array}{l}\text { Surgical stabilization with 2, } \\
11 \text {-hole, Unilock plates }\end{array}$ & within 6 months & $\begin{array}{l}\text { Callus formation with no infiltration } \\
\text { of inflammatory cells }\end{array}$ & $\begin{array}{l}\text { Implants removed } 26 \text { months } \\
\text { post-operatively at owner's request }\end{array}$ \\
\hline 7 & NT & within 8 months & & \\
\hline 8 & NT & within 12 months & & \\
\hline 9 & $\begin{array}{l}\text { Phenylbutazone }(2.2 \mathrm{mg} / \mathrm{kg} \\
\text { PO SID for one week) }\end{array}$ & within 18 months & & \\
\hline 10 & NT & within 6 months & & \\
\hline 11 & $\begin{array}{l}\text { Surgical stabilization with 2, } \\
10 \text { hole, Unilock plates }\end{array}$ & within 4 months & $\begin{array}{l}\text { Callus formation with mild } \\
\text { infiltration of inflammatory cells }\end{array}$ & $\begin{array}{l}\text { Implants removed } 12 \text { months } \\
\text { post-operatively at owner's request }\end{array}$ \\
\hline 12 & NT & within 18 months & & \\
\hline 13 & $\begin{array}{l}\text { Phenylbutazone }(2.2 \mathrm{mg} / \mathrm{kg} \\
\text { PO SID for two weeks) }\end{array}$ & within 6 months & & \\
\hline 14 & NT & within 24 months & & \\
\hline 15 & $\begin{array}{l}\text { Surgical stabilization with 4, } \\
10 \text { hole, Unilock plates }\end{array}$ & within 4 months & $\begin{array}{l}\text { Callus formation with chronic } \\
\text { infiltration of inflammatory cells }\end{array}$ & $\begin{array}{c}\text { Implants removed } 3 \text { months } \\
\text { post-operatively because of } \\
\text { infection }\end{array}$ \\
\hline
\end{tabular}

NT, no treatment; LTF, lost to follow-up; PO, per orally; SID, once a day | NT, keine Therapie; LTF, keine Verlaufskontrolle möglich; PO, per oral; SID, einmal täglich 
Suture line periostitis is described as an inflammatory response to instability or direct trauma (Dixon 2014). However, of the four samples examined histologically, only two cases had infiltration of inflammatory cells. None of the swellings, including the two with histologic signs of inflammation, were painful. Therefore, further information that would potentially elucidate the etiology of SP was not found in our study. Trauma or previous surgical sinusotomy is described as a possible direct cause (Dixon 1991, Tremaine and Freeman 2006, Fenner et al. 2018), but this did not occur in any of the cases in the present study. Instability of the nasofrontal suture line was seen in all cases that underwent surgical treatment and has been discussed as a predisposing factor for the development of SP (Manso-Diaz and Taeymans 2012). However, the cause of this instability and the influence of compression forces during mastication (Rafferty and Herring 1999) are not clear. Spontaneous resolution of SP over a period of 12 to 18 months has been described (Dixon 2014), which was in general agreement with the results of the present study. In the 12 cases that received conservative treatment or were not treated, resolution of the bony swelling occurred within 18 months in seven, but took longer than 18 months in the remaining cases. In contrast, surgical treatment resulted in resolution of bony changes in less than six months. However, a meaningful comparison is difficult because only a few cases were treated surgically.

The incidence of horses with SP presented to our clinic was relatively low. Even though a definitive diagnosis of SP was possible using radiography, CT was superior for determining the extent of affected suture lines. Based on our findings, surgical fixation in horses with SP leads to more rapid resolution of bony changes and therefore should be considered as a treatment option. Further studies are needed to determine the etiology of SP.

\section{Manufacturers' addresses}

1 Streuli Pharma AG, Uznach, Switzerland

${ }^{2}$ MSD Animal Health, Lucern, Switzerland

${ }^{3}$ E. Graeub AG, Bern, Switzerland

${ }^{4}$ Arovet AG, Dietikon, Switzerland

${ }^{5}$ Vétoquinol $A G$, Ittigen, Switzerland

${ }^{6}$ Roche Pharma AG, Reinach, Switzerland

7 Synthes, Oberdorf, Switzerland

${ }^{8}$ MSD Animal Health, Lucern, Switzerland

\section{Conflict of interest}

The authors declare that they have no conflict of interest.

\section{Acknowledgements}

The authors would like to thank Dr. Udo Hetzel for the histologic section and assessment.

\section{References}

Agroscope (2016) Wirtschafts-, Gesellschafts- und Umweltpolitische Bedeutung des Pferdes in der Schweiz, Stand 2016, Ed: E.D.f.W. Schweizerische Eidgenossenschaft, Bildung und Forschung WBF.

Carslake H. B. (2009) Suture exostosis causing obstruction of the nasolacrimal duct in three horses. New. Zeal. Vet. J. 57, 229-234; DOI 10.1080/00480169.2009.36907

Dixon P. M. (1991) Swellings of the head region in the horse. In Practice 13, 257-263; DOI 10.1136/inpract.13.6.257

Dixon P. M. (2014) A review of swellings of the frontal region of the equine head. Equine Vet. Educ. 26, 365-371; DOI 10.1111/eve.12187

Evans K. E., Mc Greevey P. D. (2006) Conformation of the equine skull: a morphometric study. Anat. Histol. Embryol. 35, 221-227; DOI 10.1111/j.1439-0264.2005.00663.x

Fenner M. F., Verwilghen D., Townsend N., Simhofer H., Schwarzer J., Zani D. D., Bienert-Zeit A. (2018) Paranasal sinus cysts in the horse: Complications related to their presence and surgical treatment in 37 cases. Equine Vet. J. 51, 57-63; DOI 10.1111/evj.12959

Gibbs C., Lane J. G. (1987) Radiographic examination of the facial, nasal and paranasal sinus regions of the horse. II. Radiological findings. Equine Vet. J. 19, 474-482; DOI 10.1111/i.2042-3306.1987.tb02648.x

Klein L., Sacks M., Fürst A. E., Del Chicca F., Grest P., Jackson M. A. (2014) Fixation of chronic suture exostosis in a mature horse. Equine Vet. Educ. 26, 171-175; DOI 10.1111/eve.12111

Manso-Diaz G., Taeymans O. (2012) Imaging Diagnosis - Nasofrontal suture exostosis in a Horse. Vet. Radiol. Ultrasound 53, 573-575; DOI 10.1111/j.1740-8261.201 1.01923.x

Mcllnay T. R., Miller S. M., Dugan S. J. (2001) Use of canaliculorhinostomy for rapair of nasolacrimal duct obstruction in a horse. J. Am. Vet. Med. Assoc. 218, 1323-1324; DOI 10.2460/javma.2001.218.1323

Lane J. G., Gibbs C., Meynink S. E., Steele F. C. (1987) Radiographic examination of the facial, nasal and paranasal sinus regions of the horse: I indications and procedures in 235 cases. Equine Vet. J. 19, 466-473; DOI 10.1 11 1/j.2042-3306.1987.tb02647.x

Rafferty K. L., Herring S. W. (1999) Craniofacial sutures: morphology, growth, and in vivo masticatory strains. Morphology 242, $167-$ 179; DOI 10.1002/(SICI) 1097-4687(199911)242:2<167:AIDJMOR8 > 3.0.CO;2-1

Ramzan P. H., Payne R. J. (2005) Periapical dental infection with nasolacrimal involvement in a horse. Vet. Rec. 156, 184-185; DOI 10.1136/vr.156.6.184

Tremaine W. H., Dixon P. M. (2001) A long-term study of 277 cases of equine sinonasal disease. Part 2: Treatments and results of treatments. Equine Vet. J. 33, 283-289; DOI 10.2746/042516401776249787

Tremaine W. H., Dixon P. M. (2002) Diseases of the Nasal Cavities and Paranasal Sinuses. In: Equine Respiratory Diseases, Eds: P. Lekeux, International Veterinary Information Service, Ithaca, NY (www.ivis.org), B0312.0302

Tremaine W. H., Freeman D. E. (2006) Disorders of the Paranasal Sinus. In. Equine Respiratory Medicin and Surgery. 1st edn., Eds: B. C. McGorum, P. M. Dixon, N. E. Robinson and J. Schumacher, Saunders Elsevier Ltd. Philadelphia, 393-407 